\title{
An Investigation of the Diversification Roles of Contractor
}

\author{
Nur Azila Adros ${ }^{1}$ \\ Dr. Nazirah Zainul Abidin
}

\author{
Article History \\ Received 2019-01-09 \\ Accepted 2019-01-17 \\ Published 2019-01-26 \\ Keywords \\ Contractor, \\ Diversification roles, \\ Construction industry
}

\section{How to cite?}

Adros, N. A., \& Abidin, D. N. Z.

(2019). An Investigation of the

Diversification Roles of Contractor.

SEISENSE Journal of Management,

2(2), 1-12. doi:

bttps:/ / doi.org/10.33215/sjom.v2i2.93

\author{
Universiti Sains Malaysia
}

Universiti Sains Malaysia

Copyright (c) 2019 The Author(s)

(cc) BY

\begin{abstract}
The construction sector is facing a period of change due to the uprising used of new technology and innovation, movement of the industry towards sustainable construction, emphasis on strategic alliances and high demand from the clients. The contractors are one of the important key players that contribute to the development of the construction industry and they are long known for their conventional roles during the construction stage by hiring subcontractors and supervising the construction works on site. However, due to current changes in the industry, the contractors' role has been evolving over the years and this has impacted their roles to change as well. This paper reviews the traditional roles of the contractor and discusses the reasons for their evolving roles in the construction industry. Finally, this paper delves into the various diversification roles of the contractor which are categorized into two which are the management and technical roles.
\end{abstract}

\section{Introduction}

Construction sector in Malaysia is categorized into the primary sector which involves activities in construction whereas the secondary sector involves the engineering field, industrial and manufacturing and others (Chuan et al., 2014). In the construction practice, the architects, quantity surveyors, and contractors must make decisions first before the project reaches the development stage (Hughes, 1989). There are many professionals involved in the construction projects and one of them is the contractor (Herman, 2016, Ernawati and Flanagan, 2012). Contractors function as a constructor as they are involved in the physical construction of buildings and they are one of the construction players who deal and works closely with the client (Yongtao, 2008, Anyanwu, 2013, Herman, 2016).

Due to the nature of the construction industry; construction projects are deemed as difficult to manage and challenging due to its complex working culture and its condition and the numbers of people involved such as

\footnotetext{
${ }^{1}$ Corresponding author's email address: azilaadros@gmail.com
} 
the architect, subcontractors, surveyors, suppliers, and others (Arditi and Balci, 2009). Contractors play a significant role, especially during the construction stage. According' to Kabiri et al. (2012), academic works of literature and government reports have discussed and answered the questions of "who does what" by explaining on the different professional roles in construction projects. However, research carried out by Ayo (2005) found that there are misconception and misunderstanding of roles in some of the construction industry professionals. Other than that, there is a lack of suitable working knowledge on the roles of each professional during the construction projects (Anyanwu, 2013). Roles of every profession were not discussed in detail even though some textbooks have provided general details and description of each role of construction players (Ndekugri and Rycroft, 2000, Murdoch and Hughes, 2008, Kabiri et al., 2012). This study aims to discuss the traditional roles of contractors and investigate the diversification roles of contractors in the construction industry.

\section{Reasons for the Evolving Roles of Contractors in the Construction Industry}

Contractors range from sole owners to large multinational companies that hired thousands of people in their workforce and up to date, the contractors are group into different grades based on the type of projects that they are involved in, a number of workers, their company revenues and project capital (Herman, 2016). Change is a force that is continually influencing the economy, culture, and construction (McDermott, 2009). The construction industry is known as challenging and in order to successfully construct a building, few aspects should be taken into such as it requires many workers and professionals to be involved in one project (Hussin and Omran, 2009). To date, buildings are higher and more complex to construct as there are new materials, new methods, and new constructional plant each year and this the whole pace of modern life has transformed the roles of the contractor (Taylor, 1963). Due to the ever-increasing changes within the business environment, it has created an urgency for every profession to evolve (Frei and Mbachu, 2009). Thus, everyone involved in the construction industry whose roles are changing should be able to respond and adjust according to the internal and external environment (Male et al., 2007).

In the 1970s, the construction industry has undergone numerous changes and lead to changes in the methods of construction and different types of construction procurement (Alarayedh, 2005). There are few reports identified in study by Egan (1998) that have played an important role and contributed in restructuring the construction sector leading in the form of procurement that have influenced and have an impact on the changing roles of professional involved such as the engineers, contractors, subcontractors, suppliers, surveyors and manufacturers (Male et al., 2007). An increase in the complexity of building projects is due to technological advancements and constant fragmentation of the construction industry (Gidado, 2004). Construction industry has undergone radical changes over the years where we can see the changes which had major effects on the nature of the construction business as the clients' emphasize more on the delivery of a quality product in a safe and environmentally as well as delivery on time and at the right price as they demand value for money (Bhutto et al., 2004, CIRIA, 2000).

The changes in the development business and increasing demand for safety and lower defects have resulted in different resources used, different construction methods and practices and have the capacity to have an effect on the production rates (Gidado, 2004). Currently, Malaysian construction industry scenario shows that there is a shift towards the use of new technology, Building Information Modelling and venturing into green projects even though it is deemed as new among construction players. With all these changes, the way contractors perform their jobs has also transformed to adjust to the fast-paced of the construction sector. Chan (2013) pointed out that the main contractor's role has evolved, and many former contractors have become service providers instead of product providers and redefined themselves as construction managers even though the industry and academia did not realize that this change is happening. Kuhn (2007) referred the ever-changing role of the contractor and defined different choices for materials to be used, the 
construction method and lastly manages works according to the owner's requirement. As the contractors' role has evolved from time to time, many companies have expanded the services that they provide and oversee a wider range of services (Peach, 2007). In order to survive upon these challenges, the contractors should alter their own roles to adapt to the challenges. Diversification roles of the contractor are essential to suit with the increasing demand from the market.

\section{Traditional Roles of the Contractor}

A role is defined as a group of actions that represent a purposeful of the member in the community and occupying informally a defined position in social relations or known with a selected worth in society (Turner 1956). According to Heckman Jr. and Galletta (1988), the role is referred as an element of a position consisting of essential revenant actions and role refers to what social actors are expected to try and do as against what they are or however they are labeled. Contractors are the key performers within the construction industry, and they have the skills in constructing physical of the buildings (Yongtao, 2008; Anyanwu, 2013). Murdoch and Hughes (2000) described a contractor as somebody using all the required skills, providing all of the materials and plant and in order to realized the client's need. Where else CITB (2015) defined contractor as a personal or self-employed worker that handle the construction project and someone who directly communicate and involve with other staff on site. Contractors are known for their conventional roles such as responsible for preparing and handling the subcontractor's work and other personnel in a construction project.

During the nineteenth century, general contracting has emerged in Great Britain and in the meantime, the contractor's profession has developed in the United States during the 1870s (Wermiel, 2006). Contractors' profession began to emerge when building development turned out to be progressively and more complicated thus create a need to place all the works under a general contractor (AIA 1906). The contractor starts their work during the planning or design stage and plays a greater role during the construction stage where they will administer the project and organizes all the subcontractors, suppliers and equipment before handing over the project to the client (Anyawu, 2013, Saucerman, 1999). Contractor's task starts from the design phase and their responsibilities are highlighted such as to conduct constructability analysis and manage the construction process (Anyanwu, 2013).

The main contractor can subcontract numerous elements of the development works and can be accountable for their performance and coordinate the work of subcontractors consequently (APUC, 2017). Normally, before construction starts, the contractor and the client are bound through contracts which have been signed by both parties and thus, to fulfill the client's requirements, the contractor needs to use their experiences and knowledge in constructing a building and organize all the necessary resources (Yongtao, 2008). Some contractors manage the entire building process whereas others are extending their scope of activities into post-construction facility management (Murray and Appiah-Baiden, 2000).

\section{The Diversification of Contractor's Roles}

The roles of contractors have developed and undergone significant changes over the years. There are eleven new roles of contractors that have been identified in this study such as technology expert, health and safety expert, design manager, green expert and environmental monitor, service provider, BIM expert, collaborate with other stakeholders, value management, innovator, conservator, and risk analyzer. These roles of contractors are later categorized into technical and management roles.

\section{Technical Roles}

Technical roles in contractors are also referred to as hard skills, which are specific talents and expertise that a contractor can acquire and it is also known as abilities that a contractor can acquire through practice and 
learning (Kagen, 2017). There are nine roles of contractors that can be found under technical roles such as technology expert, health and safety expert, design manager, green expert and environmental monitor, service provider, BIM expert, innovator, conservator, and risk analyzer.

\section{Green Expert and Environmental Monitor}

Contractors play a vital role in the green buildings and their responsibilities confirm the success of the green building method and to realize that they need to implement and document green building measures which are totally different from the conventional projects (Rosenberg et al., 2003). According to the previous research, Samari et al. (2013) stated that contractor as one of the key players in the construction field that can encourage and reduce environmental impacts by using environmentally friendly products and new technologies by going green. Constructing a green building needs contractors to take actions for managing and designing the work relating to the minimization of environmental which has certain impacts such as improving the efficiency of the construction process, being able to conserve additional energy, water, and additional resources throughout construction and eventually having the ability to reduce the number of construction waste which can increase productivity and reduce costs of the projects which would not bring an impact on the project's schedule or budget (Qi et al., 2010).

Contractor's role in green construction starts from the design stage and they are highly involved throughout the construction stage. Information related to the cost implications for contractors that pursue green construction can be gained by the owner and designers through the early involvement of the contractor (Dalpra and Salvaterra, 2012). A cost presented to the clients may prevent them from selecting the sustainable materials to be used during in the project (Griffin, et al., 2010; Griffin, 2005). Thus, the involvement of contractor in the early phase in green projects is crucial as they will give an early price estimation and giving few options to be chosen by the client according to the client's budget and in some cases, a contractor will appoint a representative to represent those (Häkkinen \& Belloni, 2011, Griffin, 2005). Contractors that involved in sustainable construction monitored construction activities to make sure compliance with commissioning requirements, control pollution, waste disposal, indoor air quality, and site management protocol (Deane, 2004). Before installation was done, there few things that need to be carried out by the contractor as this can be vital to get the approval of building materials such as review the manufacturers' data by collecting the actual test methods, data, and costs (Dalpra and Salvaterra, 2012).

In order have better environmental benefits; contractors are encouraged to take alternative construction methods, design or supplies (Jasch, 2000, Kuhre, 1998, International Organization of Standardization, 2006, Benneth \& James, 1999, Tibor, 1996). As an environmental monitor, the contractor should commit to reducing waste control and pollution (Shen et. a.l, 2005). Construction companies have become quite adept and committed at recycling and the related job site and infrastructure as they needed to fully implement a waste minimization and job site recycling (Riley et al., 2003). It is vital to construction product, which is environmentally friendly, and evaluates the health and safety for workers involved in the product's manufacture or installation (Woolley, 2000; Edwards and Bennett, 2003). Contractors should hire well-trained employees to identify events arising from construction activities, to administrate on-site environmental aspects, and evaluate environmental impacts by using environmentally friendly products (Shen et al., 2005).

\section{Technology Expert}

Contractors play a crucial role as a technology expert in sustainable construction throughout the preconstruction and construction phase that are the most important phase (Gunhan, 2012). Throughout the preconstruction phase, contractors must develop and be ready to integrate technologies into buildings by understanding few aspects of latest technologies like the technical scope, handling estimating, scheduling, empowerment and testing aspects (Gunhan and Hatipkarasulu, 2012). Technology being used in green 
construction is more advanced and totally different than the normal conventional construction. Green technologies are employed in industrial buildings and hospitals for the waste treatment and different technologies found in green construction such as biothermal, bio-energy, geothermal and clean energy technologies such as solar, wind, and hydrogen (Gunhan, 2012).

\section{Health and Safety Expert}

Contractors are qualified to manage and coordinate an efficient 'health and safety' program for all staff onsite since they possessed data of the work activities, hazards, and also the means to regulate these hazards (Prime, 2008). In order to accomplish a harmonious approach for best practices and safety standards, the contractors and owners ought to work along to form a standard of safety process during the design stage (Tamim et al., 2017). However, owners, subcontractors, and even main contractors misapprehend this necessary role (Prime, 2008). Before the construction starts, the contractors should be responsible and ought to be blamed for the choices they make during designing a process and the owners must ensure all the safety expectations are accomplished (Tamim et al., 2017). There are five steps to oversee and coordinate an effective health program at the site by the contractors as suggested by Prime (2008) which is to identify them and correct the hazards, communicate with subcontractors, assign a certified coordinator, establish an emergency response plan and finally maintain a final record.

\section{Design Manager}

In order to maintain a competitive advantage in the industry, the contractor needs to handle the design process and reduce any waste that is being issued (Broadband and Laughlin, 2003). Design and build and turnkey are the most widely used procurements today and through design and build, contractors can appoint professionals like the architect, and consultant or engineer to handle the design and the involvement of contractors during the early stage will fulfill the client's requirements (Akintoye, 1994, Male at al., 2007, Tzortzopoulos and Cooper, 2008). The contractor will act as a design manager due to their role in the design and in certain circumstances, they may hire someone who is accountable to them such as the architect or engineer (Male at al., 2007). As a design manager, the contractor must have technical capabilities such as encourage teamwork through communication with other parties involved and solved any technical issues that were brought up (Cross and Clayburn, 1995). In sustainable construction, constructability is the design efforts within the construction phase where the contractors can implement activities easily and smoothly (CIRIA 1983). There ought to be no trouble in performing a constructability analysis if the attention is given to the details of the design such as the choice of methods and materials, construction layout space, maintaining the equipment and controls and space for installing as the contractor is involved with the weekly green team meetings (Bayraktar et al., 2010). The contractor will play their role throughout the early design stage by giving options to the clients in order to minimize the costs impacts of the projects.

\section{Service Provider}

Does a contractor provide a product or a service? According to Rogers (2013), in the United Kingdom, many contractors have described their intention to provide services, or "integrated solutions" tailored to the individual client's needs. According to Maloney (2002), the contractor provides service that is categorized into environment, distribution, and product while delivering a physical good.

\section{BIM expert}

Building Information Modelling (BIM) is outlined as an innovative approach for approaching the design, construction and operation and maintenance of the building and is claimed as a project and method simulation (Kymmell, 2008, Azhar, 2011, Azhar et al., 2012, Bryde, et al., 2013). BIM enhance safety, improves the competitiveness of contractors and reduces risks of price (Anuar and Abidin, 2015). 


\section{Innovator}

Many authors stress that innovation in a company developed from numerous activities through research and development and collaboration of companies with their customers (Rosenberg, 1993; Slaughter, 1993; OECD, 1996, 1997). As an innovator, contractors' roles in research and development provide technological innovation and in certain countries, any company that would like to invest in research and development should provide a presentation and explanation to boost up others to innovate ( $\mathrm{Na}$ et al., 2007).

\section{Conservator}

Contractors involved in conservation projects are required to be an expert with high skills in working with historic buildings. According to the Mansfield and Reyers (2000), conservation projects require high expertise and professionals involved are the historic experts, consultants, and contractor with high experience and knowledge in this type of project. If the contractor involved has a wide experience and knowledge in a conservation project, the risk is low during the refurbishment period. In Malaysia, there are few conservation projects such as the Cheong Fatt Tze Mansion, Suffolk House, Penang Peranakan Mansion and others required the expertise of contractor which are highly skilled in conservation projects.

\section{Risk Analyzer}

To achieve an improvement in project management; there is a requirement for systematic risk management approaches which will facilitate contractors for minimizing the risks (Tam and Shen, 2012). According to Enshassi et al. (2008), in order to have an effective risk preventive technique, contractors should thoughtabout obtaining updated project details and add risk premiums to time estimation during the planning stage.

\section{Management Roles}

Management roles of contractors are defined as certain abilities that the contractor should possess in order to fulfill any job requirements in the construction industry and usually these roles involves good communication, decision making, communication and good arrangement and planning (CFI, 2019).

\section{Value management}

Contractors have the capability to enhance project functions, reduce project costs and completion times through value management (Kim et al., 2016). Research carried out by Lim (2016) found that industrialized based contractor (IBS) and value management (VM) share the same goal of acquiring value for money by minimizing value through reduction of wastage and taking into consideration the standard of the aforesaid project. Due to the high potential of cost keeping, the contractors are inspired to utilize the VM analysis within the beginning of the progression without limiting on the quality (Vellu, 2001). VM is a well-known structured team approach technique that enhances the cooperation of people associated with the development and for example, once the architects, engineers, and contractors can agree on the standard components to be used as low standardization (Lim, 2016, Hamid, 2008).

\section{Collaborate with other Stakeholders}

Stiles (1985) stated that for contractors stay resilient and being an advantage other than construction companies, they need to have a successful collaboration with other parties in the industry by having a strategic alliance or through partnership. A relationship that contains trust, understanding and well-working communication between the parties is important for the project to end in success (Guangdong et al., 2017). Crouse (1991) concluded that business partnership in company comes with the benefits of the flexibility to leverage internal investments and balanced partnership relationship, target core competencies, cut back capital desires, widen product offerings and improve quality and productivity, ready to enter new markets, unfold risk and chance, new technologies and ready to satisfy the client. Another importance of collaboration within the industry is that the information transfer and learning method that is endlessly in progress (Huemer, 2004). 


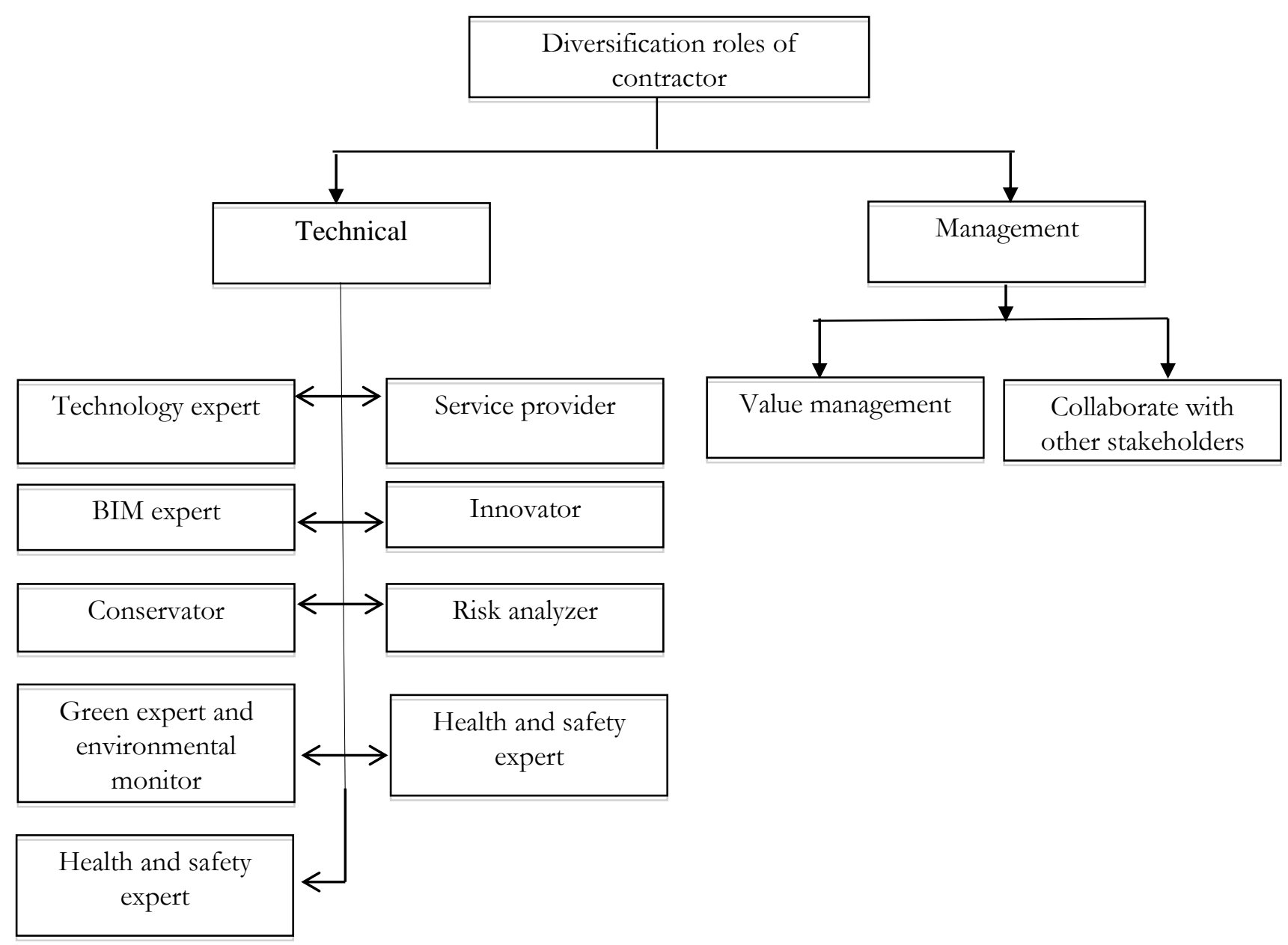

Figure 1 - Diversification of contractors' roles in the construction industry

\section{Conclusion and Future Research}

Contractors are known for their traditional role in building development process in general, is to construct the building and have the necessary skills in taking charge of the activities during the construction stage. Over the years, there are changes in the Malaysian construction industry and the changes identified are the increasing demand from the clients, the movement towards green, Building Information Modelling (BIM) and the increased adoption of technology. The question is, what are the new roles of contractors in the construction environment today? The role of contractors has shifted today and evolved from time to time and their roles now need to be re-defined. Diversification of the contractor shows that due to pressure and changes that are happening in the construction sector, they need to evolve their roles to stay competitive and relevant. They are no longer known for their common roles such as managing the subcontractors, planning and ensuring all the works at the site completed within the timeline. Contractors have diversified from their conventional roles and the finding from this study highlighted eleven new roles of the contractor such as they are now an innovator, technology expert, health and safety, designer, green expert and environmental monitor, service provider, building information modeling expert, collaborate with other stakeholders, value management, conservator and risk analyzer. This study provides valuable insight into the contractor to stay resilient and gain competitive advantage than others by showing them a clear view on their advanced roles in the current market. In the future, a framework of diversification roles of the contractor will be developed to investigate 
the changing role process of the contractor from traditional to a diversified role. Future research will also focus on the challenges, enablers and what motivates them to diversify into their new roles.

\section{References}

Akintoye, A. (1994). Design and Build: A Survey of Construction Contractors' Views. Construction Management and Economics, 12(2), 155-163.

Alarayedh, A. D. (2005). The Changing Role of Architects and Contractors.

Anuar, K. F., \& Abidin, M. H. I. Z. (2015). The Challenges in Implementing Building Information Model (BIM) for SME's Contractor in The Construction Industry, 3(1). Infrastructure University Kuala Lumpur Research Journal.

Anyanwu, C. (2013). The Role of Building Construction Project Team Members in Building Projects Delivery. IOSR-JBM, 14(1), 30-34.

APUC (2017). Guide to procuring construction projects. Retrieved from http://www.apucscot.ac.uk/uploads/Docs/pdf/Guide $\% 20$ to $\% 20$ Procuring $\% 20$ Constructin $\% 20$ Proj ects $\% 2029-6-11 . p d f$

Arditi, D., \& Balci, G. (2009). Managerial Competencies of Construction Managers. In (pp. 650- 658). Presented at the Proceedings of the Fifth International Conference on Construction in the 21st Century Collaboration and Integration in Engineering, Management and Technology, Istanbul, Turkey.

Ayo, B. (2005). Building Production Management. Lagos, Nigeria: Foresight press Ltd.

Azhar, S. (2011). Building Information Modeling (BIM): Trends, Benefits, Risks, and Challenges for the AEC Industry. Leadership and management in engineering, 11(3), 241-252.

Azhar, S., Khalfan, M., \& Maqsood, T. (2019). Building Information Modelling (BIM): Now and Beyond. CEB, 12(4), 15-28.

Bayraktar, E., Gunasekaran, A., Koh, S. L., Tatoglu, E., Demirbag, M., \& Zaim, S. (2010). An efficiency comparison of supply chain management and information systems practices: a study of Turkish and Bulgarian small- and medium-sized enterprises in food products and beverages. International Journal of Production Research, 48(2), 425-451.

Benneth, M., \& James, P. (1999). ISO 14031 and The Future of Environmental Performance evaluation. Sheffield: Greenleaf Publication.

Bennett, J., Pothecary, E., \& Robinson, G. (1996). Designing and Building a World-Class Industry. Centre for Strategic Studies in Construction.

Bhutto., K., Griffith, A., \& Stephenson, P. (2004). Integration of Quality, Health and Safety and Environment Management Systems in Contractor Organizations. In. Presented at the $20^{\text {th }}$ Annual ARCOM Conference, Heriot-Watt University: Khosrowshahi, F (Ed.).

Broadbent, J., \& Laughlin, R. (2003). Public-Private Partnerships: An Introduction, 16(3), 332- 341. Accounting, Auditing and Accountability Journal.

Bryde, D., Broquetas, M., \& Volm, J. M. (2013). The project benefits of Building Information Modelling (BIM). International Journal of Project Management, 31(7), 971-980. 
CERF. (2000). Guidelines for Moving Innovations into Practice. Working Draft Guidelines for the CERF. In. Washington, DC: International Symposium and Innovative Technology Trade Show.

CFI. (2019). Management Skills - Types and Examples of Management Skills. Corporate Finance Institute.

Chan, P. (2013). A 'Zombie' Existence: Exploring Ulrich Beck's Zombie Categories and Construction Management. In. Presented at the Procs 29th Annual ARCOM Conference, Smith, S.D and AhiagaDagbui, D.D. (Eds).

Chuan, T., Ming, T., \& Lin, A. (2014). Business Strategies of Small and Medium-Sized Contractors in Malaysia, 2(10). International Review of Basic and Applied Sciences.

CIDB. (2017). Construction Statistics Quarterly Bulletin.

CIRIA (1983). Buildability: An Assessment. UK: Special Publication.

CIRIA (2000). Integrating Safety, Quality and Environmental Management. CIRIA Report C509.

CITB. (2015). Industry Guidance for Contractors. The Construction (Design and Management) Regulations.

Cross, N., \& Clayburn Cross, A. (1995). Observations of Teamwork and Social Processes in Design. Design Studies, 16(2), 143-170.

Crouse, H. (1991). The Power of Partnerships, 4-8. The Journal of Business Strategy.

Deane, M. (n.d.). The CM's Role in Achieving LEED Certification. The Cost and Benefits of HighPerformance Buildings, 114-116. Earth Day New York.

Edwards, S., \& Bennett, P. (2003). Construction Products and Life-Cycle Thinking, 26, 57-61. United Nations Environment Programme.

Egan, J. (1998). Rethinking Construction. Department of Trade and Industry, London.

Frei, M., \& Mbachu, J. (2009). The Future of Quantity Surveying in New Zealand: Likely Changes, Threats and Opportunities. In. Presented at the 13th Pacific Association of Quantity Surveyors Congress (PAQS 2009).

Gidado, K. (2004). Enhancing the Prime Contractor's Pre-Construction Planning. J. Construct. Res., 05(01), 87-106.

Griffin, C., Knowles, C., Theodoropoulos, C., \& Allen, J. (2010). Barriers to the Implementation of Sustainable Structural Materials in Green Buildings, 369-370.

Griffin, L. (2005). Articulating the Business and Ethical Arguments for Sustainable Construction. The University of Florida.

Gunhan, S. (2012). Builders' Role: Innovative Green Technologies' Integration Process in Construction Projects.

Gunhan, S., \& Hatipkarasulu, Y. (2012). A Classroom Discussion of Applied Ethics. In. Presented at the American Society of Engineering Educators 2012 Annual Conference, Engineering Ethics Division, San Antonio, TX.

Hamid, Z., Kamar, K., Zain, M., Ghani, K., \& Rahim, A. (2008). Industrialized Building System (IBS) in Malaysia: The Current State and R\&D Initiatives, 2(1), 1-13. Malaysia Construction Research Journal. 
Heckman, R. L. J., \& Galetta, D. F. (1988). Changing Roles in a Theory Perspective. In. ICIS 1988 Proceedings.

Herman, S. (2016). The Motivation of Quantity Surveyors in the Malaysian Construction Industry. The University of Salford, United Kingdom. Retrieved January 23, 2019

Huemer, L. (2004). Activating Trust: The Redefinition of Roles and Relationships in An International construction project. International Marketing Review, 21(2), 187-201.

Hughes, W. (1989). Organizational Analysis of Building Projects. Department of Surveying, Liverpool Polytechnic.

Hussin, A. A., \& Omran, A. (2009). Roles of Professionals in Construction Industry. In Presented at the The International Conference on Economics and Administration, University of Bucharest, Romania: Faculty of Administration and Business.

Häkkinen, T., \& Belloni, K. (2011). Barriers and drivers for sustainable building. Building Research \& Information, 39(3), 239-255.

International Organization for Standardization (2006). International Standard. Retrieved from http://www.iso.org/iso/en/ISOOnline.ftrontpage

Jasch, C. (2000). Environmental Performance Evaluation and Indicators, 8(1), 79-88. Journal of Cleaner Production.

Kabiri, S., Hughes, W., \& Schweber, L. (2012). Role Conflict and Role Ambiguity in Construction Projects. In (pp. 727-736). Presented at the Procs 28th Annual ARCOM Conference, Edinburgh, UK: Association of Researchers in Construction Management.

Kagen, J. (2017). Technical Job Skills. Investopedia.

Kim, S., Lee, Y., Nguyen, V., \& Luu, V. (2016). Barriers to Applying Value Management in the Vietnamese Construction Industry, 21(2), 55-80. Journal of Construction in Developing Countries.

Kuhn, S. (2007). Preconstruction Services: Add Value with More than Just Estimating. Construction Business Owner.

Kuhre, W. (1998). ISO 14031--Environmental Performance Evaluation (EPE): Practice Tools and Techniques for Conducting an Environmental Performance Evaluation. Prentice Hall PTR.

Kymmell, W. (2008). Building Information Modeling. New York: McGraw Hill Professional.

Latham, M. (1994). Constructing the Team: Final Report of the Government/Industry Review of Procurement and Contractual Arrangements in the UK Construction Industry.

Lim, Y. C. (2016). Application of Value Management by IBS Contractors in Malaysia. Construction Management Faculty of Engineering and Green Technology Universiti Tunku Abdul Rahman.

Male, S., Bower, D., \& Aritua, B. (2007). Design Management: Changing Roles of the Professions. Proceedings of the Institution of Civil Engineers - Management, Procurement and Law, 160(2), 75-82.

Maloney, W. F. (2002). Construction Product/Service and Customer Satisfaction. Journal of Construction Engineering and Management, 128(6), 522-529. 
Mansfield, J., \& Reyers, J. (2000). Conservation Refurbishment Projects: A Comparative Assessment of Risk Management Approach. In. Presented at the Cutting Edge-The Real Estate Research Conference of the RICS Research Foundation.

Mcdermott, C. P. (2009). The future of the construction industry and the implications for construction project management and education. Iowa State University.

Murdoch, J., \& Hughes, W. (2008). Construction Contracts: Law and Management. London: Taylor \& Francis.

Murray, M., \& Appiah-Baiden, J. (2000). Difficulties Facing Contractors from Developing Countries: Problems and Solutions. In. Johannesburg, South Africa: University of Witwatersrand.

Mustafa Kamal, E., \& Flanagan, R. (2012). Understanding Absorptive Capacity in Malaysian Small and Medium Sized (SME) Construction Companies. J of Eng., Design and Tech, 10(2), 180-198.

National Audit Office. (2011). Modernizing Construction. National Audit Office, London.

Ndekugri, I. E., \& Rycroft, M. E. (2000). JCT 98 Building Contract: Law and Administration. ButterworthHeinemann.

OECD (1996). Innovation, Patents and Technological Strategies. OECD, Paris.

OECD (1997). Proposed Guidelines for Collecting and Interpreting Technological Innovation Data.

Othman, O. I. (2012). Application of Value Management at Design Stage - A Case Study (Identifying the Awareness Level). Universiti Teknologi Malaysia.

Peach, W. (2007). The Changing Role of Site Contractors in Retail Construction. New England Estate Journal.

Poles, M. S. (2005). Contractors' Customary Duties and Responsibilities. MP Group.

Prime, H. (2008, January 1). Prime Contractor Responsibilities. Worksafe magazine.

Qi, G., Shen, L., Zeng, S., \& Jorge, O. J. (2010). The Drivers for Contractors' Green Innovation: An Industry Perspective. Journal of Cleaner Production, 18(14), 1358-1365.

Riley, D., Pexton, K., \& Drilling, J. (2003). Procurement of Sustainable Construction Services in the United States: The Contractor's Role in Green Buildings. In (Vol. 26, pp. 66-69). Presented at the Industry and Environment: Sustainable Building and Construction, United Nations Environment Programme.

Rosenberg, H., MESM, Merson, A., \& Funkhouser, J. (2003). LEED ${ }^{\mathrm{TM}}$ and the General Contractor, or How We Stopped Worrying and Learned to Embrace Green. In. Presented at the Proceedings of the Greenbuild International Conference \& Expo, Pittsburgh, PA.

Rosenberg, N. (1993). Factors Affecting the Diffusion of Technology, 189-210. Brookfield Vt., USA: N. Rosenberg (Ed.), Perspectives on Technology, Cambridge University Press, Cambridge.

Salvaterra, G., \& Dalpra, M. A. F. (2012). The Case Study of Two Buildings in the Leed Certification in Italy: The Role of the General Contractor in Sustainable Green Buildings, 36(3), 138-148.

Samari, M., Ghodrati, N., Esmaeilifar, R., Olfat, P., \& Mohd Shafiei, M. W. (2013). The Investigation of the Barriers in Developing Green Building in Malaysia. MAS, 7(2). 
Saucerman, S. S. (1999). General contractor - Do You Know the Difference? (Did You Know There Even Was a Difference?). Construction Dimensions.

Shen, L.-Y., Lu, W.-S., Yao, H., \& Wu, D.-H. (2005). A computer-based scoring method for measuring the environmental performance of construction activities. Automation in Construction, 14(3), 297-309.

Slaughter, E. S. (1993). Builders as Sources of Construction Innovation. Journal of Construction Engineering and Management, 119(3), 532-549.

Stiles, J. (1995). Collaboration for Competitive Advantage: The Changing World of Alliances and Partnerships. Long Range Planning, 28(5), 109-112.

Strategic Forum for Construction (2002). Accelerating Change. In. London: Strategic Forum for Construction.

Tam, V. W. Y., \& Shen, L. Y. (2012). Risk Management for Contractors in Marine Projects. OTMCJ, 4(1), 403-410.

Tamim, N., Scott, S., Zhu, W., Koirala, Y., \& Mannan, M. S. (2017). Roles of Contractors in Process Safety. Journal of Loss Prevention in the Process Industries.

Taylor, F. (1963). The Functions of the Contractor in Building and Civil Engineering, 111, 622-634. Journal of the Royal Society of Arts.

Tibor, T. (1996). ISO 14000: A Guide to the New Environmental Management Standards. Chicago: Irwin Professional Publication.

Turner, R. H. (1956). Role-Taking, Role Standpoint, and Reference-Group Behavior. American Journal of Sociology, 61(4), 316-328.

Tzortzopoulos, P., \& Cooper, R. (2007). Design Management from a Contractor's Perspective: The Need for Clarity. Architectural Engineering and Design Management, 3(1), 17-28.

Wermiel, S. E. (2006). Norcross, Fuller, and the Rise of the General Contractor in the United States in the Nineteenth Century. In (Vol. 3, pp. 3297-3314). Presented at the Proc. Second International Congress on Construction History, Cambridge.

Woolley, T. (2000). Green Building: Establishing Principles, 44-56. Ethics and the built environment, ed. Warwick Fox.

Wu, G., Zuo, J., \& Zhao, X. (2017). Incentive Model Based on Cooperative Relationship in Sustainable Construction Projects. Sustainability, 9(7), 1191.

Yongtao, T. (2008, January 1). Contractor's Competitiveness and Competitive Strategy in Hong Kong, The Hong Kong Polytechnic University Department of Building and Real Estate. 